\title{
ANALISIS KETIDAKSANTUNAN BERBAHASA DI SMP NEGERI 18 KOTA BENGKULU
}

\author{
Mimik Sugiarti ${ }^{1}$, Ngudining Rahayu $^{2}$, dan Catur Wulandari ${ }^{3}$ \\ ${ }^{1,2,3}$ Program Studi Pendidikan Bahasa dan Sastra Indonesia \\ Jurusan Pendidikan Bahasa dan Seni \\ FKIP Universitas Bengkulu \\ mimiksugiarty@gmail.com
}

\begin{abstract}
Abstrak
Tujuan penelitian ini adalah untuk mendeskripsikan wujud bahasa yang tidak santun dilihat dari konteks penggunaannya dan faktor yang menyebabkan penggunaan bahasa yang tidak santun. Metode yang digunakan dalam penelitian ini adalah metode deskriptif kualitatif. Data dalam penelitian ini yaitu bahasa yang tidak santun terdapat di SMP N 18 Kota Bengkulu. Sumber data penelitian ini adalah bahasa yang digunakan siswa dan guru dalam proses pembelajaran di SMP N 18 Kota Bengkulu. Penelitian ini dilakukan pada tanggal 20 Februari sampai 20 Maret 2017. Teknik pengumpulan data menggunakan teknik rekaman. Teknik analisis data dalam penelitian ini dilakukan melalui langkah-langkah yaitu: (1) pentranskripsian data (2) pengidentifikasian data, (3) pengklasifikasian data, (4) penginterpretasian data, dan (5) penyimpulan data. Hasil penelitian menunjukkan bahwa adanya tuturan yang tidak santun berdasarkan wujud tuturan sebagai salah satu penentu kesantunan dalam berbahasa yaitu: adanya tuturan yang tidak santun berdasarkan wujud panjang pendeknya suatu tuturan, wujud urutan tuturan, wujud penggunaan kata honorifik, wujud intonasi dan isyarat kinesik, dan ditemukan juga tuturan yang tidak santun berdasarkan wujud pemakaian diksi yang tepat, serta adanya faktor penyebab ketidaksantunan dalam berbahasa yaitu: faktor dorongan rasa emosi penutur, faktor sengaja memojokkan mitra tutur, fakor mengkritik secara langsung dengan kata-kata kasar, faktor kebiasaan siswa, faktor kedudukan di kelas, dan faktor latar belakang sosial penutur. Kesimpulannya adalah pada proses pembelajaran di kelas terdapat tuturan yang tidak santun oleh pemakai bahasa yang secara sengaja maupun tidak sengaja karena ketidaktahuan pemakai bahasa dalam bertutur secara santun dan adanya faktor penyebab ketidaksantunan berbahasa.
\end{abstract}

Kata Kunci: Analisis, ketidaksantunan berbahasa, SMP Negeri 18 Kota Bengkulu.

\begin{abstract}
The purpose of this study is to describe the form of language that is not polite seen from the context of its use and the factor that couse the use of language that is not polite. The method used in this research is language that is not polite in SMP N 18 Kota Bengkulu. The data source of this rsearch is the language used by student and teachers in the learning process at SMP N 18 Kota Bengkulu. This study was conducted on 20 February to 20 Maech 2017. Data collection techniques using recording techniques. Data analysis techniques in this study is done through the step are: (1) data transcription, (2) identification data, (3) data classification , (4) data interpretation, and (5) data inference. The results showed that the existence of speech is not polite based on the form of speech as one of the determinants of politeness in the language that is: the speech is not polite based on the long form of a short speech, the form of speech sequence, the use of the word greetings,
\end{abstract}


intonation and kinesik cues, the use of appropiate diction, as well as the causes of language inkonsistency are: emotional impulse factor, deliberate intention to corner partners, factors directly criticize with harsh words, student habit factors, class position factors, and social background faktor of speakers. The conclusion is on the process of learning in the classroom there are speeches that are not polite by the language user who intentionally or unintentionally because of ignorance of language users in speaking politely and the factors causing language disability.

Keywords: Analysis, language disloyability, SMP Negeri 18 Kota Bengkulu.

\section{PENDAHULUAN}

Bahasa adalah sistem lambang bunyi yang arbitrer yang dipergunakan oleh anggota kelompok sosial untuk bekerja sama, berkomunikasi, dan mengidentifikasikan diri (Achmad dan Abdullah, 2012:10). Jadi bahasa adalah suatu alat yang berupa sistem lambang bunyi yang diucapkan oleh alat ucap manusia yang digunakan untuk berkomunikasi atau berinteraksi.

Wardhaugh (Chaer dan Agustin, 2010:15) mengatakan bahwa fungsi bahasa adalah alat komunikasi manusia baik secara lisan maupun tulisan. Bahasa berfungsi sebagai alat komunikasi, alat pemersatu bahasa artinya dengan bahasa kita dapat memahami satu sama lain apa yang dibicarakan dalam berinteraksi, membina hubungan sosial antar sesama juga merupakan fungsi dari bahasa. Tanpa adanya bahasa, tentu saja akan sangat sulit bagi manusia untuk menyampaikan kemauannya, ide, pendapat, perasaan, pesan dan sebagainya.

Bahasa memegang peranan penting dalam kehidupan masyarakat. Manusia mempergunakan bahasa sebagai sarana untuk berkomunikasi. Dalam kehidupan bermasyarakat sering kali kita temui penggunaan bahasa pada musyawarah kerja, rapat di kantor desa, dan juga dalam lingkungan sekolah khususnya pada saat proses pembelajaran di kelas, mereka menggunakan bahasa resmi atau formal. Di lingkungan masyarakat dan sekolah penggunaan bahasa terdapat bahasa yang santun dan tidak santun dalam berkomunikasi.

Dewasa ini, masyarakat sedang mengalami perubahan menuju era globalisasi. Setiap perubahan masyarakat melahirkan konsekuensi-konsekuensi tertentu yang berkaitan dengan nilai dan moral, termasuk peralihan bahasa dari bahasa santun menuju kepada bahasa yang tidak santun. Seperti yang terjadi di masyarakat ketika berkomunikasi terdapat tuturan yang pendek disertai dengan intonasi suara yang keras dan juga terkadang tidak menggunakan kata sapaan begitu juga yang terjadi di sekolah. Penggunaan bahasa di Sekolah Menengah Pertama (SMP) juga terdapat bahasa yang tidak santun yang digunakan oleh guru atau pun siswa khususnya pada saat proses pembelajaran berlangsung.

Menurut Leech (Pranowo, 2009: 11) berbahasa santun adalah berbahasa yang dapat diterima oleh orang lain karena tidak melukai hatinya. Kesantunan berbahasa dalam berkomunikasi dapat memberi efek baik bagi penutur dan lawan tutur sehingga pesan yang ingin disampaikan dalam komunikasi terebut dapat diterima oleh lawan tuturnya dengan tidak membuat sakit hati lawan tutur yang menerima pesan yang disampaikan oleh penutur.

Siswa seharusnya menggunakan bahasa Indonesia yang baik dan benar dalam proses pembelajaran di sekolah, 
akan tetapi kenyataan di lapangan masih ada terdapat siswa menggunakan bahasa melayu bengkulu di kelas yang tidak sesuai dengan konteks penggunaannya, hal ini dapat menimbulkan adanya penggunaan bahasa yang tidak santun oleh siswa, kesulitan siswa untuk menggunakan bahasa indonesia di kelas, ketidakseganan siswa terhadap guru, adanya hak asasi manusia yang membuat guru tidak bisa bertingkah lebih dalam menasehati siswanya, masih ada siswa yang acuh tak acuh bahkan ribut pada saat guru menjelaskan materi pembelajaran di kelas

Berdasarkan permasalahan di atas maka penulis tertarik untuk melakukan penelitian tentang penggunaan bahasa yang tidak santun dilihat dari penyebab ketidaksantunannya dan konteks penggunaannya yang digunakan oleh guru dan siswa dalam berkomunikasi atau berinteraksi. Maka judul dalam penelitian ini yaitu "Analisis Ketidaksantunan Berbahasa di SMP Negeri 18 Kota Bengkulu" dengan lingkup penelitian yang mengkaji penggunaan bahasa yang tidak santun di lingkungan sekolah pada saat proses pembelajaran berlangsung dengan bahasa yang formal dan penggunaan bahasa yang tidak santun tersebut disebabkan oleh faktor ketidaksantunan berbahasa.

\section{METODE}

Metode yang digunakan dalam penelitian ini ialah metode deskriptif dengan pendekatan kualitatif. Metode deskriptif adalah metode yang bertujuan membuat deskripsi atau gambaran secara sistematis, faktual, dan akurat mengenai data, sifat-sifat serta hubungan fenomenafenomena yang diteliti (Djadjasudarma, 1993: 8). Pendekatan kualitatif adalah salah satu metode penelitian yang bertujuan untuk mendapatkan pemahaman tentang kenyataan melalui proses berpikir induktif (Basrowi \& Suwandi, 2008: 1).

Data dalam penelitian ini adalah bahasa tidak santun yang digunakan dalam komunikasi guru dengan siswa dan siswa dengan siswa saat proses pembelajaran berlangsung di kelas dengan menggunakan bahasa yang formal, pemilihan kelas dan guru di rekomendasikan oleh pihak Tata Usaha (TU) di SMPN 18 Kota Bengkulu. Sumber data dalam penelitian ini adalah bahasa yang digunakan siswa saat belajar di kelas dan bahasa yang digunakan guru saat mengajar yaitu guru mata pelajaran IPA dan PKN.

Peneliti sebagai instrumen dalam penelitian ini dengan mengunakan alat rekam yang berupa handphone. Teknik pengumpulan data dalam penelitian ini adalah teknik rekaman. Jadi dalam penelitian ini penulis mendapatkan data dengan cara merekam proses pembelajaran di kelas. Adapun Langkahlangkah yang dilakukan dalam menganalisis data yaitu: mentranskripsian data, pengidentifikasian data, pengklasifikasian data, penginterpretasian data, dan menyimpulkan.

\section{HASIL DAN PEMBAHASAN}

\section{Panjang pendeknya suatu tuturan}

Menurut Rahardi (2005:119) Semakin panjang sebuah tuturan akan menjadi semakin santunlah tuturan tersebut. Sebaliknya, semakin pendek sebuah tuturan akan cenderung semakin tidak santun.

Berikut terdapat data tuturan tidak santun yang merupakan tuturan yang pendek yang disebabkan oleh faktor dorongan rasa emosi penutur:

D5/T21 Siswa-siswa : Suaranya gak dengar.

D5/T22 Siswa 6: Saturnus (mengulangi jawaban dengan suara yang keras)

D5/T23 Siswa: Hahahahha

Konteks tuturan: 
Tuturan ini terjadi antara siswa dengan siswa pada saat proses pembelajaran IPA di kelas IX 1. Tuturan ini disampaikan oleh siswa kepada siswa saat mengulangi jawaban atas soal yang telah dibacanya. Tuturan ini terjadi dalam situasi kelas yang kurang tenang karena siswa-siswinya sibuk dengan obrolan pribadi masing-masing.

Pada data (D5/T23) terdapat tuturan yang tidak santun karena dilihat dari wujud tuturannya yang langsung atau pendek. Tuturan itu hanya satu kata yang dituturkan oleh siswa saat mengulangi jawaban atas soal yang dibacakannya. Tuturan langsung tersebut bermakna tidak santun karena tidak ada basa-basi atau celotehan yang membuat tuturan tersebut menjadi santun.

Kata saturnus tersebut dituturkan siswa dengan suara yang tinggi dan raut muka yang sinis seperti orang yang kesal terhadap sesuatu. Tuturan tersebut disampaikan siswa dengan ekpresi wajah yang seperti melihat atau berbicara kepada seorang musuh karena terlalu kesal atas sikap teman-temannya yang menertawakannya karena suaranya kecil.

Alternatif pembenaran pada data (D5/T23) tersebut sebaiknya menggunakan kalimat yang lebih panjang seperti berikut ini:

Siswa: baiklah saya ulangi, jawabannya adalah saturnus

\section{Urutan tuturan}

Menurut Rahardi (2009:121)urutan tuturan berpengaruh besar terhadap santun atau tidaknya suatu tuturan yang digunakan saat berututur, karena tuturan yang tata letaknya urut akan mempermudah seorang memahami maksud dari tuturan itu sendiri.

Data di bawah ini merupakan tuturan yang tidak santun disebabkan oleh faktor dorongan rasa emosi penutur:
D2/T4 Guru: Nomor lima siapa tadi. Silahkan

D2/T5 Siswa :Apa yang dimaksud dengan gelombang jelaskan, gelombang adalah getaran yang merambat melalui suatu medium

D2/T6 Guru : Masih rame ya, kalian ini ya ribut trus, trus. Biar nanti ibu suruh ke depan awas kau ya, main trus kerjanya itu. Sony ngapain jadi duduk di situ sony, duduk mu tadi di mana.

D2/T7 Siswa : Di situ bu. Gak kelihatan bu.

Konteks tuturan:

Tuturan ini terjadi antara guru dengan siswa saat pelajaran IPA berlangsung di kelas VIII 5 SMPN 18 Kota Bengkulu. Tuturan ini dituturkan oleh guru kepada siswanya yang bernama Sony ketika siswa itu pindah tempat duduk saat pelajaran berlangsung. Guru bermaksud untuk menegur siswa yang bernama Sony karena ia selalu ngobrol saat pelajaran berlangsung. Tuturan ini terjadi dalam situasi kelas yang ribut.

Data D2/T6 merupakan tuturan yang tidak santun, meskipun jika dilihat dari status sosialnya kedudukan seorang guru lebih tinggi dari pada siswa tapi tetap saja tuturan guru tersebut dikatakan tidak santun karena tuturan itu tidak berurutan sehingga maknanya sulit dipahami oleh penutur, dengan suara yang lantang dan nada yang marah serta dituturkan oleh seorang guru yang memang dari suku batak membuat tuturan itu semakin terlihat tidak santun.

Suatu tuturan jika tidak berurutan akan menimbulkan sebuah tuturan yang tidak santun. Karena urutan dalam tuturan sangat berpengaruh terhadap santun tidaknya suatu tuturan. Meskipun terlihat tidak penting akan tetapi urutan tuturan sangat diperlukan dalam bertutur untuk menentukan santun atau tidaknya suatu tuturan tersebut.

Alternatif pembenaran pada tuturan data D2/T6 ialah jika kalimat 
tersebut diperbaiki kata-katanya dan urutan tuturannya, seperti di bawah ini:

Guru: anak-anak tolong diam.

\section{Penggunaan kata honorifik atau kata sapaan penghormatan}

Menurut Pranowo (2009:13) penggunaan pilihan kata honorifik yaitu ungkapan hormat untuk berbicara dan menyapa orang lain seperti kata sapaan ibu, bapak, saudara, adik, kakak, dan lain sebagainya.

Data di bawah ini merupakan tuturan yang tidak santun yang disebabkan oleh faktor latar belakang sosial siswa:

D3/T6 Guru: Kita lanjut inti tadi berada pada

D3/T7 Siswa 2: Dalam (dengan nada berteriak).

Konteks tuturan:

Tuturan di atas terjadi antara siswa dengan guru di kelas IX 2, saat pelajaran IPA berlangsung. Tuturan ini disampaikan oleh salah satu siswa yang menjawab pertanyaan dari gurunya mengenai kelanjutan materi yang disampaikan setelah terganggu oleh siswa yang masuk kelas untuk meberikan pengumuman. Tuturan itu terjadi dalam situasi kelas yang ribut dan salah satu siswa dengan suara yang keras menjawab pertanyaan dari gurunya.

Tuturan di atas tidak menggunakan kata sapaan sama sekali terhadap mitra tuturnya. Kata dalam pada tuturan di atas bermakna seperti bermain-main dalam menjawab pertanyaan padahal siswa tersebut bertutur dengan seorang guru yang seharusnya dihormati dan dargai karena seorang guru adalah orang yang patut kita hormati yang telah berjasa dalam pendidikan kita.

Alternatif pembenaran pada data tersebut, penutur harusnya menggunakan kata sapaan serta kalimat yang panjang agar mitra tutur merasa dirinya dihargai oleh penutur, tuturan tersebut antara lain:

Siswa: Dalam matahari Bu.
4. Intonasi dan isyarat-isyarat kinesik tuturan

Menurut Rahardi (2005:123) intonasi dalam bahasa lisan sangat menentukan santun tidaknya pemakaian bahasa. Intonasi terdiri dari panjang pendeknya suara, tinggi rendahnya suara, keras lembutnya suara, jeda, irama, dan timbre. Intonasi juga dipengaruhi oleh isyarat-isyarat kinesik yang dimunculkan lewat bagin-bagian tubuh penutur antara lain: ekspresi wajah, sikap tubuh, gerakan jari jemari, gerakan tangan, ayunan lengan, gerakan pundak dan gelengan kepala.

Intonasi dan isyarat-isyarat kinesik dalamsuatu tuturan menentukan santun atau tidaknya suatu tuturan itu sendiri. sebuah tuturan yang intonasinya keras disertai gerakan tubuh seperti pada data di bawah ini merupakan tuturan yang tidak santun dan tuturan ini disebabkan oleh faktor sengaja memojokkan mitra tutur, berikut datanya:

D4/T9 Siswa3:Apa yang dimaksud dengan lalu lintas perdagangan?

D4/T10 Siswa1: Ay tidak ada sampai ke situ materi kami

D4/T11 Siswa: Hahhaha

D4/T12Siswa 3: Tidak ada dalam materi kami mi.

D4/T13 Siswa 4: Tanggung jawab, tanggung jawab

D4/T14 Siswa5: Harus jawab

D4/T15 Siswa6: Jawablah, masih nyambung itu dengan materi kelompok kamu.

D4/T16 Siswa7: Jawab kami tadi jawab semua.

D4/T17Siswa8: Harus jawab

D4/T18 Siswa9: Jawab, jawab.

D4/T19 Seluruh siswa: Jawab, jawab, jawab. Konteks tuturan:

Tuturan pada data di atas terjadi antara siswa dengan siswa di kelas VII 6 saat diskusi kelompok berlangsung pada mata pelejaran $P K n$. Tuturan itu dituturkan oleh beberapa 
siswa dari kelompok lain yang sengaja memaksa mitra tutur untuk menjawab pertanyaan yang diajukan. Situasi kelas pada tuturan di atas ramai seperti pasar, semua siswa ribut dalam sebuah diskusi kelompok.

Beberapa tuturan di atas merupakan tuturan tidak santun karena tuturan-tuturan di atas disampaikan oleh siswa-siswa dengan suara yang tinggi, ekpresi wajah yang mendesak atau dengan sengaja memojokkan mitra tuturnya di depan umum dengan menggunakan isyarat kinesik berupa jari telunjuk yang menunjuk ke arah mitra tutur sehingga mitra tutur merasa dirinya dipojokkan oleh penutur.

Alternatif pembenaran pada beberapa tuturan di atas sebaiknya salah satu siswa dari kelompok yang tidak maju pada saat persentasi berlangsung berbicara untuk mewakili kelompok lain sehingga mitra tutur tidak merasa dipojokkan seperti itu, berikut alternatif pembenarannya:

Siswa: Maaf kalau pertanyaan saya keluar dari materi kelompok kalian.

\section{Pemakaian diksi atau pilihan kata yang tepat}

Menurut Pranowo (2009:9) pemakaian diksi atau pilihan kata yang tepat saat bertutur dapat mengakibatkan atau menimbulkan pemakaian bahasa yang santun. Hasil penelitian di atas penulis menemukan 6 tuturan yang tidak santun pada pemekain diksi yang tidak tepat saat bertutur.

Pemilihan kata yang tepat juga dapat menentukan santun atau tidaknya suatu tuturan, karena jika pemilihan kata saat bertutur tidak tepat dan mitra tutur merasa tidak dihargai atau dihormati maka tuturan tersebut merupakan tuturan yang tidak santun. Berikut data tuturan yang tidak santun yang disebabkan oleh faktor mengkritik langsung dengan kata-kata yang kasar yang penulis temukan saat penelitian berlangsung:
(D1/T5)Guru : Ya, periode dan frekuensi, ya kan. Periode... mana sih ini,

(D1/T6)Siswa : Selang waktu yang diperlukan untuk melakukan getaran,

(D1/T7)Guru : Dinamakan priode. Ya ampun gak ada lagi tulisan yang lebih buruk lagi dari ini ya?

(D1/T8)Siswa : Hahahahaha.

Konteks tuturan:

Tuturan di atas terjadi antara guru dengan siswa saat pelajaran IPA berlangsung di kelas VIII 5. Tuturan ini dituturkan oleh seorang guru pada saat membaca tulisan siswanya di papan tulis, dengan gaya tuturan seperti meremehkan dan merendahkan mitra tutur di depan umum. Situasi pembelajaran di kelas pada tuturan ini awalnya tenang namun muncul suara keributan setelah adanya tuturan yang tidak santun oleh gurunya.

Data D1/T7 merupakan tuturan yang tidak santun karena pemilihan kata yang tidak tepat oleh guru saat bertutur, sehingga mitra tutur merasa dirinya direndahkan depan teman-sekelasnya. Meskipun pada status sosialnya bahwa kedudukan seorang guru memang lebih tinggi dari pada siswa, akan tetapi seorang guru juga mempertimbangkan atau memilih kata yang tepat sebelum berucap sehingga tuturannya santun agar dapat diteladani oleh siswa-siswanya di kelas.

Tuturan pada data D1/T7 dituturkan oleh guru dengan latar belakang sosialnya berasal dari suku batak, memang masyarakat suku batak memiliki gaya berbicara yang lantang dan tegas akan tetapi dalam bertutur juga seorang memperhatikan pilihan katany dalam bertutur, apakah santun atau tidak dan apakah tuturan itu dapat diterima oleh mitra tutur atau tidak.

Alternatif pembenaran pada data D1/T7 ialah menggunakan pilihan kata yang tepat dalam mengkritik tulisan seseorang di depan umum, seperti data di bawah ini:

D1/T7 siswa: maaf sebelumnya nak, tulisanmu dirapikan lagi ya. 


\section{PENUTUP}

\section{Kesimpulan}

Pada proses pembelajaran di kelas terdapat tuturan yang tidak santun dilihat dari wujud tuturan dalam menentukan santun tidaknya suatu tuturan, wujud tuturan tersebut yaitu: (1) Tuturan itu berupa wujud panjang pendeknya suatu tuturan. (2) Wujud tuturan yang berupa urutan tuturan. (3) Penggunaan kata sapaan penghormatan. (4) Wujud yang berupa intonasi dan isyarat kinesik suatu tuturan. (5) Pemilihan diksi atau kata yang tepat.

Selain itu tuturan yang tidak santun juga dipengaruhi oleh beberapa faktor yang dialami oleh si penutur yaitu: (1) Faktor dorongan rasa emosi penutur. (2) Faktor sengaja memojokkan mitra tutur. (3) Faktor mengkritik secara langsung dengan kata-kata yang kasar.(4) Faktor kebiasaan siswa. (5) Faktor kedudukan di kelas dan (6) Faktor latar belakang sosial penutur.

Jadi pada proses pembelajaran di kelas terdapat tuturan yang tidak santun oleh pemakai bahasa yang secara sengaja maupun tidak sengaja karena ketidaktahuan pemakai bahasa dalam bertutur secara santun dan adanya faktor penyebab ketidaksantunan berbahasa

\section{Saran}

Berdasarkan hasil penelitian ini, ada beberapa hal berupa saran yang ingin disampaikan oleh penulis yaitu:

1. Hasil penelitian ini diharapkan dapat dijadikan salah satu referensi untuk lebih meningkatkan lagi penggunaan bahasa yang santun oleh warga sekolah, seperti guru dan siswa saat proses pembelajaran di kelas berlangsung.

2. Hasil penelitian ini diharapkan agar pembaca lebih memahami bagaimana berbahasa yang santun, lebih mengerti tentang hal-hal kesantunan dalam bertutur.

\section{DAFTAR PUSTAKA}

Achmad dan Abdullah Alek. 2013. Linguistik Umum. Jakarta: Erlangga.

Basrowi, \& Suwandi. 2008. Memahami Penelitian Kualitatif. Jakarta: Rineka Cipta.

Chaer Abdul dan Agustina Leoni. 2010. Sosiolinguistik Perkenalan Awal. Jakarta: Rineka Cipta.

Djadjasudarma, Fatimah. 1993. Metode Linguitik Ancanagn Metode Penelitian dan Kajian. Bandung: PT Eresco.

Pranowo. 2009. Berbahasa Secara Santun. Yogyakarta: Pustaka Pelajar.

Pranowo. 2009. Kesantunan Berbahaa Tokoh Masyarakat Ditinjau Dari Aspek Pragmatik. Yogyakarta: Universitas Sanata Dharma.

Rahardi, Kunjana. 2005. Pragmatik Kesantunan Imperatif Bahasa Indonesia. Jakarta: Erlangga. 